MUHASEBE VE FINANS INCELEMELERI DERGISI

Dergi Anasayfası: https://dergipark.org.tr/tr/pub/mufider

\title{
ENTEGRE RAPORLAMADA PAYDAŞLAR İLE İLIŞKILLERINN ROLÜ
}

\section{THE ROLE OF STAKEHOLDER RELATIONSHIPS IN INTEGRATED REPORTING}

\section{Özben GÜLDOĞAN ${ }^{a *}$}

a* Sorumlu Yazar, İmir Katip Çelebi Üniversitesi Doktora Öğrencisi, ozben_guldogan@hotmail.com, ORCID: 0000-0002$6027-9467$.

\section{MAKALE BILGILERİ}

\section{Makale Tarihçesi:}

Gönderilme Tarihi 04.03.2020

Düzenleme 17.03.2020

Kabul Tarihi 26.03.2020

Anahtar Kelimeler: Entegre

Raporlama, Sürdürülebilirlik

Raporlaması, Paydaşlar ile

İlişkiler

Jel Kodlart: M14, M40, M41

\begin{tabular}{c}
\hline DERLEME \\
\hline BENZERLIK/ PLAGIARISM
\end{tabular}

Ithenticate : \%21

\section{ARTICLE INFO}

Article history:

Received 04.03.2020

Revised 17.03.2020

Accepted 26.03.2020

Keywords: Integrated Reporting,

Sustainability Reporting,

Stakeholder Relations

Jel Codes: M14, M40, M41

\section{ÖZET}

Çă̆ımızın en önemli sorunsalı haline gelen "değer yaratma" kavramı, pek çok alanda ve disiplinde araştırma konusu olmuş, bir çok kavram ve prensibin gelişimine katkıda bulunduğu gibi muhasebe ve finans alanında Finansal Raporlamanın günümüzde geldiği son nokta olan Entegre Raporlamanin oluşumuna da temel hazırlamıştır. Entegre Raporlama felsefesi öncelikli olarak paydaşlarla olan iliş̧kilerin önemini yansitmaktadır. Çünkü değer sadece bir kuruluş tarafindan veya ilgili kuruluşun kendi bünyesinde değil, kuruluşun bütün paydaşları ile olan ilişkileri yoluyla yaratılır. Bu çalışmanın amacı, dünya arenasında büyük önem atfedilen entegre raporlamanın oluşumuna etki eden olguların entegre raporlama literatürü kapsamında irdelemesini yapmaktır. Bu olguların görece önemlerinin belirginleşmesi gerek dünyada gerekse ülkemizde entegre raporlamanın doğru anlaşılması ve gelişme sürecine katkıda bulunması açısından oldukça önemlidir. Bu bağlamda çalı̧̧mada entegre raporlama felsefesini gün ışı̆̆ına çıkaran kavramlar tarihsel süreç içerisinde ele alınmış ve son olarak entegre raporlama klavuz ilkelerinden Paydaşlar ile İlişkiler ilkesinin önemi değerlendirilmiştir 
the integrated reporting and development process both in the world and in our country. In this context, the concepts that bring the integrated reporting philosophy to light have been handled in the historical process and finally, the importance of the Relations with Stakeholders principle, which is one of the integrated reporting guidelines, has been evaluated.

\section{GíRiş}

Yaşadığımız global dünyada gerek çevrede yaşanan tahribat ve doğal afetlerin gerekse ekonomik krizlerin birbirine olan bağıntılarının daha hissedilir ve farkedilebilir olması, bireylerin çevresine ve yaşadığı dünyaya olan hassasiyetini değiştirmiş; çevresel, sosyal ve finansal olmak üzere yaşantılarının her alanında daha yüksek bir bilinç düzeyini harekete geçirmiştir. Artık kuruluşlardan salt finansal performansları değil, finansal performans yaratırken kullandığı kaynakların ve dahası toplum ve çevre için bir değer yaratıp yaratmadıklarının açıklaması beklenmektedir. Yaratılan değerin kısa, öz ve anlaşılır şekilde paydaşlara aktarılabilmesinde önemli bir araç olarak ortaya çıkartılan entegre raporlama, başta Güney Afrika, Kuzey Amerika, Çin, Latin Amerika ve Doğu Asya'da bulunan ülkeler olmak üzere birçok şirket tarafindan kullanılan bir raporlama şekli haline gelmiştir.

Günümüzde artık pek çok kuruluş salt hissedarları için uzun vadeli karlılık sağlamayı değil, aynı zamanda istihdam yaratmak, toplumun beklentilerini karşılayacak yenilikler üretmek, yerel üretimi teşvik etmek gibi sosyal değerleri de yaratmay 1 hedeflemektedir. Hissedarlar ve yatırımcılar öncelikli olarak kuruluşun kendisi için yarattı̆g 1 değere odaklansa da aslında ilgili kuruluşun diğer paydaşları için yarattı̆̆ 1 değer, uzun vadede o kuruluşun kendi değer yaratma kabiliyetini oluşturmaktadır.

Şirketin stratejisi hakkında içgörü kazanmak, zamanı aşan değer yaratmayı kuruluşun nasıl sağlayacağı ve iş modeli yatırımcıların yatırım kararlarını ve geri dönüşümünü etkileyen başlıca faktör haline gelmektedir. (IIRC, Creating Value :6)

Entegre raporlamanın özünü oluşturan husus bir kuruluşun yarattığ 1 (veya tahrip ettiği) değerleri ve bu değere ilişkin tüm etmenleri tespit etmek ve paydaşlarla olan iletişimin etkin ve verimli bir zemine oturtulmasını sağlamaktır (Aras ve Sarığlu, 2015).

Paydaş düşüncesinin temellerine bakıldığında bunun Adam Smith'in öncülüğünü yaptığı Ekonomik Teori'ye kadar uzandığı görülmektedir. Smith'in 1759'da "The Theory of Moral Sentiments" ve 1776 'da "The Wealth of Nations" isimli eserlerinde ifade ettiği gibi ekonomik etkileşimler karşılıklı faydacılığın söz konusu olduğu bir ilişki içerisindedirler ve şirketler bu iki faydayı birlikte sağlayabildikleri taktirde etkin olarak çalışmış kabul edilmelidirler. Bilindiği üzere Adam Smith'in teorisi bu dönemde işletmeleri kapalı bir organizasyon olarak kabul etmiș ve çevresindeki hiç bir değişkenden etkilenmediğini varsaymıştır. Fakat 1950'lerdeki Kalite Hareketiyle birlikte tüketiciler bilinçlenmeye başlamış, çeşitli lobi faaliyetleri ile desteklenen çevrenin korunmasına yönelik talepler işletmelerin davranışlarının diğer işletmeleri ve en geniş anlamda toplumu etkileyebileceği gerçeğini ortaya çıkarmıştır. Böylece işletmenin dışarıdan etkilenmeye kapalı bir organizasyon olduğu varsayımı terkedilerek diş çevre dinamikleri tarafından etkilendiği kabul edilmeye başlanmıştır. Akabinde yönetim anlayışında da köklü değişiklikler meydana gelmiştir. İşletmelerin dışarıya açı bir organizasyon olduğunun farkedilmesiyle birlikte 20 . yüzyılın ikinci yarısından itibaren Kurumsal Sosyal Sorumluluk tartışmaları literatürde yerini almaya başlamıştır. Kısa süre içerisinde çok fazla destek bulan bu yaklaşım Pay Sahipleri Teorisi, Paydaş Teorisi ve Paydaş Modeli gibi birçok teorinin temelini de oluşturmuştur (Garriga ve Domenec, 2004). Kurumsal sosyal sorumluluk yaklaşımı "İșletmenin rolü ne olmalıdır?" sorusuna cevap vermektedir (Yamak ve Süer, 2005). Etkin kurumsal sosyal sorumluluk bilincine sahip işletmeler yarattıkları değerlerin ve aldıkları kararların sorumluluğunu almaktadırlar. $\mathrm{Bu}$ anlamda en üst düzey yönetiminin bu konuda yol gösterici olması, sosyal sorumluluk anlayışlarını açıkça belirtmesi, bu konuda etkileşimde bulunduğu ilgi gruplarını net olarak tanımlaması, faaliyetlerini sonuç odaklı olarak icra etmesi ve nihayet yapılanlar hakkında hesap verebilmesi gerekmektedir (Özkol vd., 2005).

$\mathrm{Bu}$ amaçla işletmeler, kurumsal sosyal sorumluluk uygulamaları ile ilgili çıkar gruplarını bilgilendirmek amaciyla mevcut mali tablolara ek olarak faaliyet raporları içinde veya ayrıca çeşitli biçimlerde kurumsal sosyal sorumluluk raporları hazırlamaya yönelmişlerdir. Ancak bu raporlar genellikle faaliyetlerin niteliksel boyutu ile ele alındığı, parasal boyutu, maliyeti ve faaliyetlerin işletme performansı üzerindeki etkileri gibi hususlar hakkında ayrıntılı bilgi içermeyen raporlar olmuştur. İşletmelerin gerek çıkar gruplarına gerekse doğal çevrede yarattığ tahribatın (faydanın) parasal nitelikli olması söz konusu faaliyetlerin muhasebe disiplini çerçevesinde ele alınmasını gerektirdiğinden sosyal muhasebe ve sosyal raporlama kavramları gündeme gelmiş, akabinde pek çok raporlama adı altında çeşitli raporlama modelleri oluşturulmuştur (Yazan, 2015). Teoride ve uygulamadaki farkl1lıklar sonucunda, çevre muhasebesi, sosyal muhasebe, sosyal 
sorumluluk muhasebesi, kurumsal yönetişim ile stratejik yönetim ve sürdürülebilir raporlaması gibi pek çok raporlamayı kapsamak amacıyla Entegre Raporlama kavramı ortaya çıkmıştır (Yanık, 2012). Entegre raporlama entegre düşünce biçimi üzerine inşa edilen ve bir kuruluş tarafından zaman içinde yaratılan değerin bir entegre raporun ve değer yaratma sürecinin tüm unsurlarının diğer ilgili etkenlerinin tespit edilip yayımlanmasını içeren bir süreçtir (IIRC, 2013). Dolayısıyla etkin bir entegre rapor, entegre düşünme (integrated thinking) doğrultusunda geleneksel raporlamayı içerecek şekilde fakat çok daha kapsamlı bir raporlama modeli olarak daha birbiriyle bağlantılı ve ileriye dönük kararların alınmasını kolaylaştıran bir raporlama modeli olmaktadır (Aras ve Sarıoglu, 2015). 2013 yılında yayımlanan Uluslararası Entegre Raporlama Çerçevesinde Entegre Raporlama oluşumunun en önemli amaçlarından birinin sermayenin geniş tabanı için hesap verebilirlik ve yönetilebilirlik öğelerinin güçlendirme unsurlarını ve bunların birbirleri ile olan bağımlılıklarının anlaşılmasını mümkün kılarak; kısa, orta ve uzun vadede değer yaratma hedefine odaklanan entegre düşünceyi oluşturmak ve karar alma ve harekete geçme mekanizmalarını geliştirmek olarak ifade edilmektedir (IIRC, 2013).

Entegre düşünce bir kuruluşun faaliyetlerine ne kadar fazla dahil edilirse bilgiler arasındaki bağıntılar yönetim raporlamasına, analizlere ve karar verme sürecine ve dolayısıyla entegre rapora o kadar doğal bir şekilde aktarılır (IIRC, 2013). Bununla birlikte entegre raporlama olgusunun teoride getirdiği önemli yeniliklerin uygulama aşamasında zorluklarla karşılaştığ gözlemlenmektedir. Bu anlamda entegre raporlama kavramının oluşumuna etki eden kavramların anlaşılması entegre raporlamanın özümsenmesi açısından oldukça önemlidir.

Çalışmada entegre raporlamanın evrilme süreci içerisinde öne çıkan kavramlar tarihsel süreç içerisinde ele alınmış; entegre raporlama literatürü incelenerek entegre raporlamanın en önemli Klavuz İlkelerinden biri olan Paydaşlarla ilişkiler İlkesi; bir kuruluşun temel paydaşlarıyla kurduğu ilişkilerin doğası ve kalitesi hakkında bilgi sağlaması ve kuruluşun paydaşların meşru ihtiyaç ve isteklerini ne ölçüde anladığını ve karşıladığını göstermesi gerektiği noktasında hesap verebilirlik ilkesi perspektifinde değerlendirilmiştir.

\section{ENTEGRE RAPORLAMANIN OLUŞUMUNA ETKİ EDEN KAVRAMLAR}

Genel Kabul Görmüș Muhasebe İlkeleri’nden Sosyal Sorumluluk Kavramı, Muhasebenin organizasyonunda, muhasebe uygulamalarının yürütülmesinde ve mali tabloların düzenlenmesi ve sunulmasında, belli kişi veya grupların değil, tüm toplumun çıkarlarının gözetilmesi ve dolayısıyla bilgi üretiminde gerçeğe uygun, tarafsız ve dürüst davranılması gereğini ifade eder. $\mathrm{Bu}$ kavram, muhasebenin işlevini yerine getirme hususundaki sorumluluğunu belirtmekte ve muhasebenin kapsamını, anlamın1, yerini ve amacinı göstermektedir. Yine 31/12/2005 tarihinden sonra başlayan hesap dönemleri için uygulanmak üzere ilk olarak 16/01/2005 tarih ve 25702 sayıl1 Resmi Gazetede yayımlanan TMS 1 Finansal Tabloların Sunuluşu Standardının 7. madde 6. bendinde; "Bir ihmalin veya yanlış raporlamanın kullanıcıların ekonomik kararlarını etkileyip etkilemeyeceğinin ve bunun önemli olabileceğinin değerlendirilmesi, bu kullanıcıların özelliklerinin dikkate alınmasını gerektirir." şeklinde belirtilmektedir. Finansal Tabloların Hazırlanması ve Sunuluşuna İlişkin Kavramsal Çerçevenin 25 inci Paragrafında ise "Kullanıcıların işletme, ekonomik faaliyetler ve muhasebeyle ilgili makul derecede bilgiye sahip olduklar1 ve bu bilgileri makul bir gayretle değerlendirdiklerinin varsayıldı̆̆g”" ve "Bu nedenle, değerlendirmede bu özelliklerdeki kullanıcıların ekonomik kararlar alırlarken nasıl etkileneceklerinin de dikkate alınması gerekir." şeklinde ifade edilmiștir. Buna göre uygulamada yer alan standartın temelinde finansal tablo kullanıcılarının karar almalarında kullanacakları bilginin doğru ve güvenilir olması yatmaktadır. Dolayısıyla hazırlanacak finansal raporların sadece finansal bilgileri içermesi bir yana, aynı zamanda finansal olmayan bilgileri de içermesi gerektiği açıtır ve anılan bentler aynı zamanda muhasebenin sürdürülebilir gelişme üzerindeki önemine de dikkat çekmektedir (Yanık ve Türker, 2012)

İlk defa Brundtland Raporu içinde 1987'de kullanılan "Sürdürülebilir Kalkınma" terimi bu raporda yayımlandıktan sonra dünya çapında genel kabul görmüștür. John Drexhage ve Deborah Murphy'nin Eylül 2010 tarihinde New York'ta sunmuş oldukları bildiride sürdürülebilirlik kavramı öz olarak gelecek nesillerin kendi gereksinimlerini giderebilme olanaklarını tehlikeye sokmadan günümüz neslinin gereksinimlerini giderebilmek olarak tanımlanmıştır (J. Drexhage 2010). 1970 lerde ise geleneksel muhasebe kavramının işletmelerin dış çevreden etkilenmediği varsayılarak sadece kendi faaliyetlerine odaklandıklarına ilişkin eleştiriler tartışılmaya başlanmıştır. Nitekim muhasebenin temel fonksiyonlarına göre kuruluşlar aynı zamanda dış çevreden gelen ve kuruluşa etkisi olan tüm faaliyetleri de raporlamalıdır. 1970 lerde ortaya çıkan bu görüşe göre, bir finansal raporlamada işletmelerin performansının daha geniş bir bakış açısı ile değerlendirilmesi gerektiği ve kurumların bütün sosyal paydaşlarının da göz önünde bulundurularak kurumların sosyal performanslarının da raporlanması gerektiği şeklindedir. Geleneksel yönetim anlayışına 
göre performans ölçümünde salt bireyin yapmış olduğu üretimin dikkate alınması; yerini çağdaş yönetim anlayışının performans ölçümü ve değerlemesine bırakmıştır. Ölçümlemelerin sabit aralıklarla ve genellikle yılda bir defa yapılması, ölçüm zamanın farklı aralıklarla yapılması dolayısıyla başarı değerlendirmesinin sağlayacağı veriden erken yararlanılmasına olanak tanıyan ve aynı zamanda işletmenin ve yönetimin performansını belirlerken müşteri ilişskileri, çalışanların motivasyonu gibi faktörleri de kapsayacak şekilde daha genel bir bakış açısıyla ve tüm etkenlerin entegre edildiği bir çağdaş yönetim anlayışı ortaya çıkmaya başlamıştır. Oysa geleneksel muhasebe ölçümlerinde kar ve verimlilik üzerine odaklanırken içe dönük bir yapı izlemekte ve sayısal veriler benimsenmekteydi. Fakat günümüzde kullanıcılar açısından sayısal veriler bir anlam ifade etmemektedir. Bu bağlamda bilgi çağında işletmeler kullanacağ1 performans ölçütlerini; işletmenin vizyon, misyon ve stratejilerini dikkate alarak tespit etmelidirler (Usul, 2007). Bu bakış açısı, kuruluşların hesap verebilir ve şeffaf olmasının gerekliliğinden kaynaklandığı gibi topluma karşı olan sorumluluğun da bir parçasıdır. Özellikle büyük kuruluşlarda, işletmelerin büyük paydaşlarına ve topluma olan sorumluluklarının bir gereği olarak sadece finansal performans raporlaması yapmalarının yeterli olamayacağı, işletmenin onlar için ve onlarla birlikte var olabileceği gerçeği karşısında kolaylıkla öngörülebilmektedir. $\mathrm{Bu}$ daha geniş bir anlamda, kuruluşların bütün paydaşlarına, hissedarlarına potansiyel yatırımcılarına ve bütün sosyal çevresine karşı sorumluluğu olarak değerlendirilmektedir (Aras, 2007).

"Sosyal Sürdürülebilirlik" kavramı üzerinde uzlaşılan tek bir tanım bulunmamakla birlikte, en kapsayıc tanımlardan bir tanesi "Formal ve informal süreçler, sistemler, yapılar ve ilişkiler varolan ve gelecek nesiller için sağlıklı ve yaşanabilir topluluklar inşaa edilmesine olanak verdiği zaman sosyal sürdürülebilirlik sağlanabilir.", "Sosyal anlamda sürdürülebilir toplumlar hem eşit, hem birbirinden farkl1, hem de birbirlerine bağlı, demokratik olup, iyi kalitede bir yaşamı mümkün kılmaktadır" şeklindedir (McKenzie 2004). Bir başka kavram ise "Sürdürülebilir Rekabetçilik" dir. Bu yaklaşıma göre önümüzdeki dönemde kuruluşlar gelecekte ortaya koyacakları stratejileri belirlerken çalışanlarını, içinde bulunduğu çevreyi, sosyal sorumluluklarını ve sürdürülebilirlik ile çevre kirlenmesine ilişkin hususları göz önünde bulundurmak zorunda kalacaklardır (Ertuna, 2012). "Sosyal muhasebe" kuruluşların faaliyetlerinin etki ettiği bütün kesimler ile doğal çevre üzerinde yarattıkları etkilere yönelik bilgilerin bir arada sunulduğu, analiz edildiği ve raporlandığ 1 bir muhasebe dalı olarak tanımlanmaktadır (Ertuna, 2012). Daha geniş bir ifadeyle sosyal muhasebe kuruluşların faaliyetlerinin ilişkili bulunduğu kesimler üzerinde oluşturduğu ekonomik, sosyal ve çevresel etkilerin ölçülmesi, analiz edilmesi, elde edilen bulguların finansal tablolar içinde veya ayrı olarak raporlanması suretiyle ilgililere sistemli bir şekilde açıklanması konusunda uzmanlaşmış muhasebe dalıdır. Özetle sosyal muhasebenin merkezinde kuruluşların sosyal sorumluluk uygulamalarına yönelik kayıt ve raporlama çalışmaları bulunmaktadır. Bu uygulamalar işletmelerin toplumsal ilişkileri, işgücü ile ilişkileri, fiziki kaynakları ve çevreye yönelik katkıları ile mal ve hizmetlere yönelik katkıları olmak üzere dört ana başlikta belirtilebilir. Bununla birlikte sosyal performans olarak da ifade edilen bu olgular kuruluşların sosyal sorumluluklarını yerine getirmekteki başarılarını tanımlamaktadır (Kaya, 2006).

Amerikan Sertifikalı Kamu Muhasebecileri Enstitüsü'nün sosyal muhasebe tanımına baktığımızda sosyal muhasebenin içeriğinin; işletmenin şimdiki faaliyetlerinin tüm çıkar gruplarını içine alarak sosyal etkilerine ilişkin bilginin geliştirilmesi, hedeflenen sosyal başarı için hedeflerin, stratejilerin ve standartların belirlenmesi ve bu hedeflere ulaşmak için gösterilen gayretlerin ne kadar etkin olduğuna dair alınan nihai kararlar şeklinde ifade edildiği görülmektedir (Özbirecikli, 2017).

"Sürdürülebilirlik Raporlaması" ise sadece sürdürülebilir gelişmeyi değil, aynı zamanda sürdürülebilir kalkınmayı da hedefleyen, kurumsal performans ile ilişkili bütün alanlarda ölçüm ve açıklama yapan, iç ve dış olmak üzere tüm paydaşlarına karşı sorumlu olma anlayışıyla faaliyet göstermeyi ilke edinen bir uygulama olarak ifade edilmektedir. Günümüzde gittikçe artan sayıda kuruluş faaliyetlerini sürdürülebilir kılmak için, uzun vadeli karlılıklarını sosyal adalet ve çevre korunmasını göz önünde bulunduran temeller çerçevesine dayandırmıştır. Gerçekten de sürdürülebilir bir ekonomiye doğru yol alma ihtiyac1 işletmelerin ve kuruluşların finansörleri, müşterileri ve diğer paydaşları tarafından anlaşılmasının zorunluluğunu doğurmuştur. Sürdürülebilirlik raporlaması kuruluşların faaliyetlerini daha sürdürülebilir kılmak için hangi hedefleri belirlemeleri gerektiğini, performanslarını ölçmelerinde kullanılacak kriterleri belirlemelerini ve yönetmelerini mümkün hale getirmektedir (GRI, 2013:4).

İşletmelerin sürdürülebilirlik raporları hazırlamalarının bir başka önemli amacı ise içinde bulundukları topluma ve ilişkili olduğu paydaşlarına karşı sosyal konulara olan duyarlılıklarını ve bağlılıklarını göstermektir. Yatırımcılar, müşteriler, düzenleyici/denetleyici kuruluşlar, savunma grupları ve gayri resmi kuruluşları içine alarak tüm paydaşların geliştirilmesi ve genişletilmesi için sürdürülebilirlik raporları bir işletmenin performansı 
hakkında doğru ve hızlı geri dönüşleri teşvik etmesi açısından önem taşımaktadır (Özbirecikli, 2017). Uluslararası genel kabul görmüş standartlar, bildirimler ve ölçütler ise sürdürülebilirlik raporlarında bulunan bilgilerin karşılaştırılabilir olmasına olanak sağlamakta ve böylelikle bütün paydaşlara bilinçli kararlar vermelerine olanak sağlayacak nitelikli bilgiyi temin etmektedir (globalreporting.org, 2020).

Günümüzde, alışılagelen "finansal muhasebe" artan bir ivme ile çok önemli bir dönüşüm yaşamaktadır ve bu dönüşüm çerçevesinde muhasebenin ilgi alanı genişlemekte, muhasebe daha geniş kitlelerin veri ihtiyaçlarına cevap vermenin yollarını aramaktadır. Bu alanlarda araştırmalar ve çalışmalar giderek artmaktadır. Yapılan araştırma ve çalışmalar "sosyal muhasebe", "sosyal ve çevre muhasebesi", "şirket sorumluluğu raporlaması", "şirket sosyal sorumluluğu raporlaması", "finansal olmayan raporlama", "sürdürülebilirlik muhasebesi" "sosyal raporlama", "sürdürülebilirlik raporlaması" gibi pek çok isim adı altında yürütülmektedir.

Görülmektedir ki; geleneksel muhasebeden gerek sosyal muhasebeye gerekse sürdürülebilirlik muhasebesine kadar geçmişten günümüze finansal muhasebenin gelişimi işletmelerin faaliyetleri (sosyal, çevresel veya ekonomik) ile bunların hem birbirleri, hem de ilişkili olduğu öğeler ile olan etkileşimi hakkında bilgi sağlayarak tüm çıkar gruplarının gözetilmesi ve korunmasi üzerine ilişkilendirilmektedir.

\section{ENTEGRE RAPORLAMANIN ORTAYA ÇIKIŞI}

Entegre raporlamanın temelleri 1994 yilında Güney Afrika'nın yeni seçilmiş başkanı Nelson Mandela tarafından kurulması sağlanan King Komitesi'nin yayımladığı King raporuna dayanmaktadır. Nitekim bu raporda 34 kuruluşun finansal olmayan bilgilerinin açıklanması istenirken, 2002 yılında yayımlanan King II raporunda şirketlerin tüm ilgili paydaşlarının dahil edilmeleri ve dahası sorumluluklarını finansal sonuçları ile birlikte sosyal ve çevresel konuları da kapsayacak bir şekilde genişletmeleri talep edilmiştir (Aras ve Sarığlu, 2015). 2000 li y1llar çevresel bilinç, sosyal bilinç, sosyal soumluluk oluşumlarının devinimiyle geçerken; finansal tablolar ise içeriklerinin karmaşıklığı, bilgiler arası bağlantı kopuklukları, karşılaştırılabilirliklerinin güçlüğ̈̈, gelecekdeki risk ve firsatların belirlenmesi açısından yatırımcıya doğru bir perspektif sağlamakta yetersiz kalması yönleriyle yoğun bir şekilde eleştirilmiştir.

Yatırımcılar finansal başarıdan öte çevresel, sosyal ve yönetimsel başarının da kuruluşların değerini etkilediğini ve bu değerin sürdürülebilir bir niteliğe bürünmesine doğrudan etki ettiğini farketmiş; akabinde şirketlerden bu konularda da bilgilendirme yapmasını talep etmeye başlamışlardır.

$\mathrm{Bu}$ dönemde sadece yatırımcı talepleri değil, kuruluşların toplumun geleceğini şekillendirmede üstlendikleri role ilişkin olarak da talepler belirmeye başlamıştır. Endüstri devriminden bu yana dünyanın kaynaklarını tüketmek pahasına büyüyen şirketlerin artık problemin değil, çözümün bir parçası olması talep edilmektedir. Günümüzde artık şirketlerin sadece ne kadar kâr elde ettiği tek kriter olmaktan çıkmış, bu kârın nasıl elde edildiği önemli bir kriter olarak belirmiştir. Artık şirketlerden; faaliyetlerini sosyal, çevresel ve ekonomik etkilerini tetkik etmesi, izlemesi ve raporlamasi; süreklilik arz eden, uzun vadeli taahhütlerde bulunması beklenmektedir. $\mathrm{Bu}$ durum paydaşlarının güvenini kazanarak pazarda iyi bir itibar elde etmek isteyen şirketlerin paydaşlarına ve topluma karşı olan sorumluluklarını yeniden tanımlamasına ve paydaşlarının ihtiyaçlarına çözüm sunacak yeni bir raporlama modeli geliştirmesine neden olmuştur (Aras ve Sarıoğlu, 2015).

2010 yılında Johannesburg Borsas1, borsaya kote tüm şirketlerin entegre rapor yayımlanmasını, yayımlamayanların ise açıklama yapmasını (report or explain) zorunlu kılmış ve böylece Güney Afrika, entegre raporlamayı borsaya kote şirketlere zorunlu hale getiren ilk ülke olmuştur (International Integrated Reporting Council- IIRC).

Uluslararas1 arenada ise entegre raporlamanın kurumsal zemini yine 2010 y1linda BM Global Compact, GRI, Uluslararas1 Muhasebeciler Federasyonu (International Federation of Accountants-IFAC), Dünya Bankas1 (the World Bank), Dünya Ekonomik Forumu (World Economic Forum- WEF) gibi dünyanın önde gelen kuruluşlarının da üyesi olduğu Uluslararası Entegre Raporlama Konseyi ile kurulmuştur. Bu konseyde sadece kuruluşlar değil, aynı zamanda Microsoft, Nestle, HSBC gibi şirketlerin temsilcileri, akademisyenler ve yatırımcılar da bulunmaktadır.

Uluslararası genel kabul görmüş bir entegre raporlama çerçevesi hazırlamay1 kendine misyon edinen IIRC dünyanın dört bir yanından akademisyenler, sivil toplum temsilcileri, özel sektör, kamu temsilcilerinin yoğun emek ve katkılarıyla 2013 yılının Aralık ayında Uluslararası Entegre Raporlama Çerçevesini yayımlamıştır. IIRC yayınladığı entegre raporlama çerçevesinde entegre raporu, bir kuruluşun stratejisinin, kurumsal yönetiminin, performansının ve beklentilerinin kuruluşun dış çevresi bağlamında kısa, orta ve uzun vadede değer yaratmayı nasıl sağlayacağının kısa ve öz bir şekilde bildirilmesi şeklinde tanımlamış olup, bu çerçeve entegre rapor hazırlayıcılarına referans olma niteliğinde olduğundan oldukça önem taşımaktadır (IIRC, 2013). 
Ülkemiz de dünyada yaşanan bu gelişmeler karşısında tamamen duyarsız kalmamış ve önemli adımlar atmıştır. Bağımsız Kurucu Üye Prof. Dr. Güler Aras, Borsa Istanbul, Türk Sanayicileri ve İşadamları Derneği-TÜSİAD, IIRC Türkiye Büyükelçisi, Global Compact Türkiye, Türkiye Kurumsal Yönetim Derneği (TKYD), SKD Türkiye, , Argüden Yönetişim Akademisi, Çimsa ve Garanti Bankası 'nın kurucu üyeleri olduğu "Entegre Raporlama Türkiye Ağı" Şubat 2017 de kurulmuş olup gerek entegre raporlamanın gerekse gerekçesini oluşturan entegre düşünce kavramının komuoyuna doğru bir şekilde aktarılması çalışmalarına başlanmıştır (entegreraporlamatr.org, 2020).

Türkiye 'den Çimsa Çimento Sanayi ve Ticaret A.Ş. Şubat 2017 'de Entegre Faaliyet Raporu yayınlayan ilk reel sektör şirketi olurken bunu Aslan çimento, Adana Çimento, Argüden Yönetişim Akademisi, Türkiye Kalkınma ve Sınai Bankası, Garanti Bankası, Borsa İstanbul, Yıldız Teknik Üniversitesi Finans Kurumsal Yönetim ve Sürdürülebilirlik Araştırma Merkezi, Kadıköy Belediyesi ve son olarak Türkiye Vakıflar Bankasi izlemiştir (entegreraporlamatr.org, 2020).

\section{ENTEGRE RAPORLAMADA PAYDAŞLAR ILE ILIŞKILLEIIN HESAP VEREBİLIRLIK İLKESİ DEĞERLENDİRILMESI}

Uluslararas 1

Entegre

Raporlama Çerçevesinde Paydaşlar ile İlişkiler ilkesi; bir entegre raporun, kuruluşun temel paydaşlarıyla kurduğu ilişkilerin doğası ve kalitesi hakkında bilgi sağlaması ve kuruluşun paydaşlarının meşru ihtiyaç ve isteklerini ne ölçüde anladığını, hesaba kattığını ve karşıladığını göstermesi gerektiği şeklinde ifade edilmiştir. Bununla birlikte paydaşlar da kuruluşun değer yaratma kabiliyetini etkileyen ekonomik, çevresel ve toplumsal sorunlar dahil olmak üzere kendileri için önemli konular hakkında faydalı bilgiler sağlayacaktır. $\mathrm{Bu}$ bilgiler kuruluşa aşağıdaki konularda yardımc1 olabilir: (IIRC, 2013:17) anlamak

- Paydaşların değer algısının ne olduğunu

- Henüz yaygin olarak ilgi çekmeyen ancak önemi giderek artan trendleri belirlemek

- Risk ve firsatlar dahil olmak üzere maddi konuları belirlemek

- Strateji geliştirmek ve değerlendirmek

- Riskleri yönetmek

- Maddi konulara verilen stratejik ve açıklanabilir yanıtları da içeren faaliyetleri yürütmek.

Dolayısıyla bir entegre raporun önceliği paydaşların gereksinim ve beklentilerinin ne kadar doğru anlaşıldığı ve önemsendiği noktasında alınan kararları; yapılan iş, performans ve sürekli etkileşim yoluyla nasıl eyleme geçirdiklerini kısa, öz ve anlaşılır bir şekilde açıklamaktır. Kuruluşlar böylelikle şeffaflığın ve hesap verebilirliğin güçlenmesine katkı sağlayarak paydaşları için gerekli güveni kazanmış olacaktır. Nitekim entegre raporlama sermayenin geniş tabanı (finansal, üretilmiş, fikri, insan kaynakları, sosyal, ilişkisel ve doğal sermaye) için hesap verebilirlik ve yönetilebilirlik öğelerini güçlendirme unsurlarını ve bunların birbirlerine olan bağımlılıklarının anlaşılmasını sağlamayı amaçlamaktadır. Bu anlamda karar verme ve harekete geçme unsurlarının geliştirilmesi kısa, orta ve uzun vadede değer yaratmaya odaklanan entegre düşüncenin ne kadar doğru anlaşıldığı ve ne kadar içselleştirildiği ile ilişskilendirilmektedir (IIRC, 2013).

Entegre raporlamanın ana odağı, aslında sermaye sağlayıcıların bilgi ihtiyaçlarıdır. $\mathrm{Bu}$ nedenle, entegre raporlamanın paydaş merkezli bir raporlama mekanizması olduğu göz önünde bulundurulduğunda, her entegre raporda ilgili kuruluşun ilişkili bulunduğu sermaye öğelerine özgü ağırlıklandırılmış bilgilere yer verilmesi gerekmektedir (de Villiers et al., 2016). Bu nedenle Uluslararası Entegre Raporlama Konseyinin (IIRC), 2013 yılında yayınladığ ${ }_{1}$ "Uluslararası Entegre Raporlama Çerçevesi” kural bazlı olmayıp, prensip bazlı bir yaklaşımı dayanak almaktadır (IIRC, 2013). Buradaki amaç her kuruluşun kendine özgü yapısal özellikleri ve dinamikleri olması nedeniyle kuruluşların, belirlenen ilke ve prensipler ile uyumlu, fakat aynı zamanda kendi özgünlügünü yansıtacak bir raporlama sistematiğini yaratmalarını mümkün k1lmaktır.

Bilimsel literatür kurumsal bilgi ihtiyacını; ajans, meşruiyet, paydaş ve hesap verebilirlik teorisi perspektiflerinden analiz etmiştir (Boiral, O. ve Heras-Saizarbitoria I., 2020). Ana akım literatüre göre hesap verebilirlik öğeleri entegre raporların güvenilirliğini artırarak paydaş sorumluluğuna katkıda bulunmaktadır. Diğer paydaşların bakış açıları incelediğinde ise, hesap verebilirlik türleri farklı paydaş grupları için farklı olmaktadır. Bunun nedeni, farklı paydaş gruplarının genellikle kurumsal bilgi aramada farklı hedefleri bulunduğundandır. Örneğin, hissedarlar değer yaratma ile ilgili bilgilere ihtiyaç duyarken, diğer paydaş grupları doğal çevre veya sosyal hedeflerle daha fazla ilgilenebilirler.

Uluslararas1 Entegre Raporlama İlke ve Prensiplerinin hesap verebilirlik ilkesi ile etkinliğine ilişkin ilk çalışma olan Thomson ve arkadaşlarının 2014 yılında yaptığ 1 araştırmada; entegre raporlama anlatılarındaki hesap verebilirlik çabalarının Uluslararası Entegre Raporlama İlke ve Prensiplerine nazaran esas olarak hazırlayıcıların ve paydaşların görüşleri tarafından belirlendiği tespit edilmiştir. $\mathrm{Bu}$ anlamda kuruluşların paydaş ilişkilerinin kalitesi ve 
etkinliğinin önemi bu çalışmanın akabinde yapılan diğer pek çok araştırma ile desteklenmiştir. Diğer taraftan aynı yıllarda Brown ve Dillard (2014) tarafindan Entegre Raporlamaya; entegre raporlamanın paydaş yönetimine, paydaşlara hesap verebilirlik öğelerinden daha fazla odaklandığını iddia eden bir eleştiri getirilmiştir. Söz konusu çalışmada bu durumun, tüketiciler, çalışanlar, tedarikçiler, yerel topluluklar, işgücü gibi paydaşlarla sendikalar, sosyal hareketler, hükümetler ve yerli toplulukların arasında daha geniş ve daha açık diyaloglar yapmayı engellediği ifade edilmektedir (Brown ve Dillard, 2014). Bu bağlamda entegre raporların paydaşlar tarafindan nasıl algılandığ sorunsalı ön plana çıkmış ve buna ilişkin yapılan pek çok çalışmada kurumsal rapor hazırlayıcılarının entegre raporlamayı farklı ve tutarsız bir alan olarak algıladıkları öne sürülmüștür (örneğin Flower, 2015 Perego, 2016; Chaidali ve Jones 2017; Feng ve diğerleri, 2017de Villiers et al., 2017; Slack, 2018 vb.). Özellikle IR'nin faydalarının belirsizliği, yeterli ve net rehberlik eksikliği, yüksek hazırlık maliyetleri, raporun formatı ve süresi gibi hususlar kurumsal rapor hazırlayıcılarının ve profesyonellerinin motivasyonunu ve Uluslararası Entegre Raporlama Konseyinin (IIRC) genel kompozisyonuna ilişkin güveni azaltan en belirgin faktörler olduğu belirtilmiştir (Perego, 2016). Bununla birlikte entegre raporlamanın şeffaflık idealinin ancak; hesap verebilirlik sürecinin kurumların açıkladığı bilgilerin güvenilir, maddi ve sürdürülebilirlik performanslarının gerekçeleriyle tutarlı olduğu kabul edilen titiz bir doğrulama sürecine dayandırılarak yürütülmesiyle gerçekleştirilebileceği bir çok ampirik çalışma ile doğrulanmıştır (örneğin Boiral ve Henri, 2017; Manetti ve Toccafondi, 2012; Rupley ve diğerleri, 2017; Martínez-Ferrero ve GarcíaSanchez, 2018; Reimsbach ve diğerleri, 2018; Gibassier, 2018 vb.).

Kuruluşların değer yaratma kabiliyetleri üzerine de yapılan pek çok araştırma bulunmaktadır ve bu araştırma sonuçları da bizi ilk olarak hesap verebilirlik öğesine götürmektedir. Örneğin dünya akademik yazında en meşhur araştırmalardan biri sayılan Lai ve arkadaşlarının (2018) dünyanin en büyük üçüncü sigortacilık grubu olan Generali şirketinde yaptıkları çalışmada; Lai ve arkadaşları anılan şirketin değer yaratma sürecini ortaya çıkararak hesap verebilirlik özelliğine etki eden en önemli faktörü ortaya çıkarmaya çalışmışlar ve bunun da daha geniş ve daha sade mesajlar yoluyla artan çeşitlilikte bir paydaş iletişimi olduğunu, daha basit bir ifadeyle kuruluşların paydaşlarıyla anlamlı diyalog kurma çabalarının en önemli etken olduğunu tespit etmiş; aynı zamanda bir kuruluşun finansal paydaşlarının o kuruluşun finansal raporlarının ana adresi olduğunu belirtmişlerdir (Lai, 2018).
Hesap verebilirlik ilkesi ile ilgili yapılan pek çok araştırmanın ana nedeni hesap verebilirliğin değer yaratma sürecinin ana besleyicisi durumunda olmasından kaynaklanmaktadır. Çünkü anılan ilke bir kuruluşun faaliyet ve çıktılarının ilişkili bulunduğu bütün sermaye öğelerinin bilinçli kullanma yönetimi ile sorumluluğu kavramları ile uygulanmaktadır. Günümüzde, çalışanlar, müşteriler, yatırımcılar, devlet kurumları ve düzenleyiciler dahil olmak üzere tüm paydaşlar iş organizasyonlarının yarattı̆̆ 1 değer ve yaratılan değerin pek çok bileșeni ve bunların faaliyetleriyle artık yakından ilgilenmektedir. (Örneğin yaratılan değerin maliyeti, alternatif maliyeti, temel girdilerinin yaratılmak istenen değer ile etkileşimi, yaratılan değerin sürdürülebilirliği vb.)

Yatırımcilar yatırım kararlarını alırken, şirketlerin yarattıkları değere ve buna ilişkin sürdürülebilirlik yaklaşımını dikkate alıp almadıklarını göz önünde bulundurmaktadır. Sosyal, çevresel ve kurumsal risk yönetimini başarıyla sürdürebilen kuruluşlar kamuoyundaki itibarlarını yükselterek gerek ulusal gerekse uluslararası yatırım portföyünün ilgisini çekebilmekte ve kurumlarının sermayeye ulaşım kabiliyetlerini yükseltmektedir. Aynı zamanda yasal mevzuatların ötesinde sürdürülebilirlik uygulamalarını iş modeli olarak süreçlerine dahil eden kurulușlar uzun vadede faaliyet maliyetlerini azaltmaktadırlar. Diğer taraftan faaliyetlerinin çevresel etkilerini iyi yönetemeyen kuruluşlar ise kaynakların azalmasıyla artan birim maliyetlerine bağlı olarak sürdürülebilirliklerini sağlamakta çeşitli zorluklarla karşı karşıya kalmaktadır (Gücenme Gençoğlu, 2016).

\section{SONUÇ}

Akademi ve iş dünyasında yaşanan devinim ve dönüşüm, paydaş kapsamını ve paydaşların taleplerini değiştirmiş kurumsal raporlamanın da bu dönüşüme ayak uyduracak şekilde gelișmesine sebep olmuştur. Finansal raporlamadan çevresel raporlamaya, çevresel raporlamadan sosyal raporlamaya, sosyal raporlamadan sürdürülebilirlik raporlamasina ve nihayet entegre raporlamaya kadar uzanan bu süreçte kuruluşlar varlıklarını korumak ve sürdürülebilir kılmak için yarattıkları değerin ve bu değeri ne pahasına oluşturduklarının toplumun onayından geçmek zorunda olduğu gerçeği ile karşılaşmışlardır. Kuruluşların sadece raporlama şekillerinin değil, aynı zamanda sahip oldukları rol ve edinimlerinin de değișimi ile sonuçlanan bu farkındalık; kuruluşların paydaşları ile olan ilişkilerini etkin bir zemine oturtmaları zorunluluğunu ortaya çıkarmıștır.

Günümüzde şirketlerin maddi manevi her anlamda sahip olduğu varlıklar ve bu varlıklar ile 
zamanının ötesinde bir değer yaratmak için nasıl bir strateji izleyeceği hakkında doğru bir içgörü kazanmak yatırımcıların karar alma sürecini etkileyen başlica faktör durumundadır. Nitekim entegre raporlama kavramı bu ihtiyacın karşılanmasının bir izdüşümü olarak ortaya çıkmıştır. Çünkü finansal sermaye sağlayıcılara aktarılan bilginin kalitesini artırmak; sermayenin daha rasyonel dağılımına imkan vererek üretimin artmasına olanak sağlayan en önemli etkendir. $\mathrm{Bu}$ anlamda entegre raporlama, kurumsal raporlama için farklı raporlama seçenekleri yaratması ve kuruluşların süreç içerisinde değer yaratma kabiliyetine etki eden bütün unsurları içerecek şekilde daha etkili ve entegre bir yaklaşım ortaya koyması açısından hayati bir yenilik getirmektedir.

Çalışmada entegre raporlama araştırmalarının nasıl geliştiğine dair bir iç görü kazanmak hedeflenmiştir. $\mathrm{Bu}$ doğrultuda yapılan araştırmalar tarandığında araştırma bulgularında en fazla tartışılan olgulardan birinin kuruluşların paydaşları ile olan iletişimi olduğu gözlemlenmiştir. Paydaşlar ile olan doğru etkileşimin değer yaratma sürecine entegre edilmesinin ilgili kuruluşun hesap verebilirlik mekanizmalarının güçlendirilmesi ile olurlu olacağ 1 göz önüne alınırsa gelecek çalışmalar için kuruluşların hesap verebilirlik öğelerinin etkinliğini zedeleyen hususlara ilişkin araştırmalar entegre raporlamanın gelişim sürecine katkıda bulunabilir.

Uluslararas1 Entegre Raporlama Konseyi entegre raporlamanın dayatmacı bir yöntemi dışlayarak kuruluşların uygulama suretiyle uzun

\section{KAYNAKÇA}

Adams, C. A. (2004). The ethical, social and environmental reporting - performance portrayal gap. Accounting, Auditing \& Accountability Journal.

Aras, G. (2007). Kurumsal sosyal sorumluluk: muhasebe ve denetim uygulamalarına yansımaları. İç Denetim Dergisi, 3(20), 5.

Aras, G., ve Sarığlu G.U. (2015). Kurumsal Raporlamaya yeni bakış: Entegre Raporlama. Tüsiad

Brown, J. ve Dillard, J. (2014) Integrated reporting: on the need for broadening out and opening up. Accounting, Auditing \& Accountability Journal, Vol. 27 No. 7, pp. 1120-1156

Boiral, O., \& Heras-Saizarbitoria, I. (2020). Sustainability reporting assurance: Creating stakeholder accountability through hyperreality? Journal of Cleaner Production, 243, 118596 vadede faydasını fark edip kalıcı bir hal almasını ilke edinmesi gerektiğini, önemi özümsenmeden hazırlanacak bir entegre raporlamanın kuruluşun bir uyum faaliyeti olmaktan öteye gidemeyeceğini ve uzun vadede alınabilecek faydayı azaltacağını belirtmektedir. Yapılan çalışma bulguları bu düşünce ile paralellik göstermektedir. Gerçekten de entegre raporlama felsefesinin doğru anlaşılması ve içselleştirilmesi bir kuruluşun tüm paydaşlarının karş1lıklı eş güdümü ve gelişimi ile mümkün olmaktadır. Uluslararası Entegre Raporlama Konseyi Uluslararası Entegre Raporlama Paydaşlar ile İlişkiler ilkesinin, entegre raporlamanın özünü oluşturan ilke, norm ve öğeler içerisinde nihai anlamda Entegre Raporlamanın esas vizyonuna ulaşmasını sağlayacak katalizör bir ilke olduğu görülmektedir.

Entegre raporlama, organizasyonların faaliyetlerinin doğal sermaye üzerindeki etkilerini tanımasını ve iletmesini sağlayan bir başlangıç noktasıdır ve entegre raporlamanın maddi ve düşünsel manada bütün paydaşlar tarafından ulaşılabilir kılınması kuruluşların entegre raporlama gelişim sürecini hızlandıracaktır. $\mathrm{Bu}$ durum paydaşların değişen taleplerinin karşılanması için şeffaflık ve hesap verebilirlik öğelerinin kalitesinin arttırılmasını zorunlu kılmaktadır.

Boiral, O., \& Henri, J. F. (2017). Is sustainability performance comparable? A study of GRI reports of mining organizations. Business \& Society, 56(2), 283-317.

Chaidali, P. P., \& Jones, M. J. (2017). It'sa matter of trust: Exploring the perceptions of Integrated Reporting preparers. Critical Perspectives on Accounting, 48, 1-20.

De Villiers, C.; Venter, Elmar R.; Hsiao, P. C. K. (2017). Integrated reporting: background, measurement issues, approaches and an agenda for future research. Accounting \& Finance, 57.4: 937-959.

Ertuna, Ö. (2012). Muhasebe İçin Yeni Ufuklar: Sosyal Muhasebe. Muhasebe ve Finans Tarihi Araştırmaları Dergisi, (3), 5-18.

Feng, T., Cummings, L., \& Tweedie, D. (2017). Exploring integrated thinking in integrated reporting-an exploratory study in Australia. Journal of Intellectual Capital.

Flower, J. (2015). The international integrated reporting council: a story of failure. Critical Perspectives on Accounting, 27, 1-17. 
Garriga, E., \& Melé, D. (2004). Corporate social responsibility theories: Mapping the territory. Journal of business ethics, 53(1-2), 51-71.

Gibassier, D., Rodrigue, M., \& Arjaliès, D. L. (2018). Integrated reporting is like God: no one has met Him, but everybody talks about Him. Accounting, Auditing \& Accountability Journal.

GRI. (2018, 1 July). Reporting Principles and Standard Disclosures.

(https://www.globalreporting.org/resourcelibrary/ GRIG4-Part1-Reporting-Principles-and-StandardDisclosures.pdf, Erişim Tarihi, 18.03.2020)

Gücenme Gençoğlu, Ü., \& Aytaç, A. (2016). Kurumsal Sürdürülebilirlik Açısından Entegre Raporlamanın Önemi ve BIST Uygulamalar1. Journal of Accounting \& Finance, (72).

Kaya, U. (2006) İşletme-Doğal Çevre İlişkilerinin Mali Tablolar Aracılığıyla Raporlanması Ve Denetimi. Sermaye Piyasası Kurulu.

Lai, A.; Melloni, G.; Stacchezzini, R. (2018). Integrated Reporting And Narrative Accountability: The Role Of Preparers. Accounting, Auditing \& Accountability Journal, 31.5: 1381-1405.

IIRC. (2014, December). Assurance On <Ir $>$ An Introduction To The Discussion. (https://integratedreporting.org/wpcontent/uploads/2014/12/22-ICAS-.pdf, Erişim Tarihi 19.03.2020)

IIRC. (2013). Uluslararası < $<$ Er $>$ Çerevesi. (https://integratedreporting.org/wpcontent/uploads/2015/03/13-12-08-THEINTERNATIONAL-IR-FRAMEWORKTurkish.pdf, Erişim Tarihi 19.03.2020)

Drexhage, J., \& Murphy, D. (2010). Sustainable development: from Brundtland to Rio 2012. United Nations Headquarters, New York, 2010, 913.

Manetti, G., \& Toccafondi, S. (2012). The role of stakeholders in sustainability reporting assurance. Journal of Business Ethics, 107(3), 363-377.

Martínez-Ferrero, J., \& García-Sánchez, I. M. (2018). The level of sustainability assurance: The effects of brand reputation and industry specialisation of assurance providers. Journal of Business Ethics, 150(4), 971-990.

McKenzie, S. (2004). Social sustainability: towards some definitions.

Perego, P., Kennedy, S., \& Whiteman, G. (2016). A Lot Of Icing But Little Cake? Taking Integrated Reporting Forward. Journal Of Cleaner Production, 136, 53-64.
Pistoni, A., \& Songini, L. (2015). Key Tools and Frameworks for Sustainability Disclosure', Sustainability Disclosure: State of the Art and New Directions (Studies in Managerial and Financial Accounting, Volume 30).

Reimsbach, D., Hahn, R., \& Gürtürk, A. (2018). Integrated reporting and assurance of sustainability information: An experimental study on professional investors' information processing. European Accounting Review, 27(3), 559-581..

Rupley, K. H., Brown, D., \& Marshall, S. (2017). Evolution of corporate reporting: From standalone corporate social responsibility reporting to integrated reporting. Research in Accounting Regulation, 29(2), 172-176.

Özbirecikli, M. (2006). Çevresel Etik ve Sosyal Denetim: Küresel Girişimler ve Türkiye'deki Uygulamalar Üzerine Mukayeseli Bir İnceleme. Muhasebe ve Finansman Dergisi, (31), 62-77.

Özkol, E., Çelik, M., \& Gönen, S. (2005). Kurumsal sosyal sorumluluk kavramı ve muhasebenin sosyal sorumluluğu. Muhasebe ve Finansman Dergisi, (27), 134-145.

Slack, R., \& Tsalavoutas, I. (2018, June). Integrated reporting decision usefulness: Mainstream equity market views. In Accounting forum (Vol. 42, No. 2, pp. 184-198). Taylor \& Francis.

Thomson, I., Grubnic, S., \& Georgakopoulos, G. (2014). Exploring accounting-sustainability hybridisation in the UK public sector. Accounting, Organizations and Society, 39(6), 453-476.

Usul, H. (2007). Davranışsal Muhasebe. Ankara: Asil Yayın Dağıtım.

Yamak, S., \& Süer, Ö. (2005). State as a stakeholder. Corporate Governance: The international journal of business in society.

Yanık, S., \& Türker, İ. (2012). Sürdürülebilirlik Ve Sosyal Sorumluluk Raporlamasindaki Gelişmeler (Tümleşik Raporlama). İstanbul Üniversitesi Siyasal Bilgiler Fakültesi Dergisi, (47).

Yazan, Ö. (2015). Muhasebe bilgi kalitesi açısından kurumsal sosyal sorumluluk, kazanç yönetimi ve finansal performans ilişkisi (Doctoral dissertation, Doktora tezi, Karadeniz Teknik Üniversitesi, Sosyal Bilimler Enstitüsü, Trabzon).

2 Sira No'lu Finansal Tabloların Sunuluşuna İlişkin Türkiye Muhasebe Standardı(TMS 1) Hakkında Tebliğ, 16.01.2005 Tarih ve 25702 Sayılı Resmi Gazete. 
https://www.theiirc.org (Erişim Tarihi, 19.03.2020)

http://www.entegreraporlamatr.org/tr/guncel/haberler2020.aspx (Erişim Tarihi, 18.03.2020)

http://www.entegreraporlamatr.org/tr/hakkimizda/bizkimiz.aspx (Erişim Tarihi, 18.03.2020) 